\title{
Partial Onset Seizure Treatment with Adjunctive Lacosamide in Epileptic Adults: A Review
}

\section{Epileptik Yetişkinlerde Parsiyel Başlangıçlı Nöbet Tedavisinde Ek Lakosamit Tedavisi: Bir Derleme}

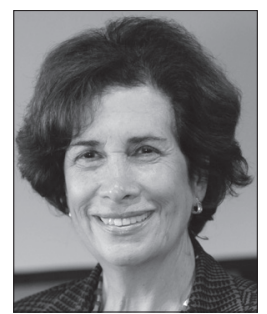

Elinor Ben-Menachem

\section{Elinor Ben-Menachem, M.D. PhD}

Institute for Clinical Neuroscience and Physiology, Sahlgrenska Academy,

University of Gothenburg, Gothenburg, Sweden

\section{Summary}

Epilepsy is a common chronic disorder of the brain and can be seen at all ages with a higher prevalence in developing countries. Adjunctive therapy with antiepileptic drugs (AEDs) is the gold standard in treatment of epilepsy. Lacosamide (LCM) is a novel AED which is approved for adjunctive therapy for the treatment of partial-onset seizures. Recently 3 Phase II/III placebo controlled clinical trials with similar designs were conducted to investigate the efficacy and safety of lacosamide (LCM) administered as adjunctive therapy with other AEDs. Data collected from those studies were pooled, re-analyzed and presented in this review article. Results revealed that LCM is well tolerated and effective in seizure reduction as adjunctive therapy in patients with uncontrolled partial-onset seizures.

Key words: Antiepileptic drugs; epileptic adults; lacosamide.

\section{Özet}

Epilepsi sık görülen, kronik, serebral bir hastalıktır ve daha çok gelişmekte olan ülkelerde, her yaştaki bireyde karşımıza çıkabilir. Günümüzde antiepileptik ilaçlar (AEI) ile adjunktif tedavi epilepsi tedavisinde standart olarak uygulanmaktadır. Lakosamit (LCM) parsiyel başlangıçlı nöbetlerin adjunktif tedavisinde kullanımı için onay almış bir AEI'tır. Yakın zamanda LCM'in etkililiğini ve güvenliliğini araştırmak amacıyla, diğer AEI'lar ile beraber adjunktif tedavi olarak LCM'in uygulandığı, benzer tasarımlı, plasebo-kontrollü faz II/III klinik çalışmalar gerçekleştirilmiştir. Bu çalışmalardan elde edilen veriler ile bir veri havuzu oluşturulmuş ve üç çalışmadan toplanan bu veriler yeniden analiz edilmiş ve bu derlemede sunulmaktadır. Sonuçlar LCM'in iyi tolere edildiğini ayrıca kontrolsüz parsiyel başlangıçlı nöbetleri olan hastalarda nöbetlerin görülme sıklığını azalttığını ortaya koymuştur.

Anahtar sözcükler: Antiepileptik ilaçlar; epilepsili yetişkinler; lakosamit.

\section{Introduction}

Epilepsy is a chronic disorder of the brain and can be seen at all ages. It is anticipated that approximately 50 million people around the world suffer from epilepsy and most of the epileptic population (nearly $80 \%$ ) is found in the developing countries. People with epilepsy and their families can suffer from discrimination and have difficulties especially in their workplaces. ${ }^{[1]}$

In developed countries, annual incidence of epilepsy is reported as 24-53 cases per 100,000 person-years. Age ad- justed incidence of all unprovoked seizures are expected to be at 61 per 100,000. ${ }^{[2]}$ Age adjusted prevalence of epilepsy varies and it is reported between 4 to 8 per 1,000 population in most studies. ${ }^{[3]}$ The average incidence of epilepsy in United States of America is estimated as 48 out of 100,000 people corresponding to 150,000 people per year. Considering the lifetime prevalence, 16.5 per 1,000 people reported that they had experienced epilepsy in their life. ${ }^{[4]}$

Epidemiologic research shows that epilepsy prevalence is higher in developing countries such as 18.5 per a popula-

Correspondence (İletişim): Elinor Ben-Menachem, M.D. PhD e-mail (e-posta): Elinor.Ben-Menachem@neuro.gu.se 
tion of $1,000 .{ }^{[5]}$ Various epidemiologic reports are available from diverse regions of Turkey mentioning similar active prevalence rates of 5 to $8.5^{[6,7]}$

Adjunctive therapy with antiepileptic drugs (AEDs) is the gold standard in treatment of epilepsy in patients with refractory epilepsy. ${ }^{[8]}$ Lacosamide (LCM) is a novel AED which is approved for adjunctive therapy for the treatment of partial-onset seizures with or without secondary generalization in patients with epilepsy aged 16 years or older. ${ }^{[9]}$

\section{Pharmacology}

\section{Mechanism of action}

Lacosamide selectively enhances the slow inactivation state of voltage-gated sodium channels (VGSCs) and increase the proportion of channels entering the slow inactivation state. Although, it does not appear to delay their recovery from slow inactivation, it has a unique effect of reducing the long-term availability of VGSCs, thus stabilising the neuronal membrane, guarding against hyperexcitability and repetitive neuronal firing. ${ }^{[10,11,12]}$

\section{Pharmacokinetics of lacosamide}

Lacosamide is rapidly and completely absorbed ( 100\% bioavailability). Tmax (time to maximum plasma concentration) is achieved within $0.5-4$ hours following oral administration. The extent and rate of lacosamide absorption is not affected by food. Less than $15 \%$ of circulating lacosamide is bound to plasma proteins. The volume of distribution of lacosamide is approximately $0.6 \mathrm{~L} / \mathrm{kg}$. The elimination half-life of the unchanged drug is approximately 13 hours. Following twice-daily dosing, steady state plasma concentrations are achieved after a 3-day period. The pharmacokinetics is dose-proportional and constant over time, with low intra- and inter-subject variability.

\section{Pharmaceutical forms}

LCM is approved and available in Turkey with 50, 100, 150 mg strengths as oral tablets. LCM's $10 \mathrm{mg} / \mathrm{mL}$ IV infusion form is also approved in Turkey. IV form of LCM provides an alternative solution for physicians and patients when oral administration is temporarily not feasible since IV formulation is proven to be bioequivalent to the oral tablet form.

\section{Drug-drug interactions}

Preclinical in vitro studies indicate that the activity of CY-
$\mathrm{P} 1 \mathrm{~A} 2,2 \mathrm{~B} 6$, and 2C9 are not induced, and CYP1A1, 1A2, 2A6, $2 \mathrm{~B} 6,2 \mathrm{C} 8,2 \mathrm{C} 9,2 \mathrm{D} 6$ and $2 \mathrm{E} 1$ are not inhibited by lacosamide. [9] Lacosamide does not inhibit or induce CYP2C19 or CYP3A4 in vivo and does not induce or inhibit hepatic microsomal enzymes..$^{[9]}$

\section{Interaction with AEDs}

In drug-drug interaction studies, lacosamide did not statistically affect the plasma concentrations of valproic acid (VPA), and lacosamide plasma concentrations were not affected by VPA. Available data indicate that the overall systemic exposure of lacosamide may be decreased by $25 \%$ during concomitant treatment with carbamazepine (CBZ), phenytoin (PHT) and phenobarbital (PB). ${ }^{[9]}$ A pooled analysis of AED plasma concentrations in subjects with partial-onset seizures showed that that steady-state plasma concentrations of levetiracetam (LEV), CBZ, lamotrigine (LTG), topiramate (TPM), oxcarbazepine (OXC), $\mathrm{PHT}$, valproate (VPA), PB, gabapentin (GBP), clonazepam (CLZ), and zonisamide (ZNS) were affected by concomitant intake of lacosamide at any dose..$^{[13,14]}$

\section{Interaction with other medicinal products}

In a drug-drug interaction study, there was no interaction between lacosamide and the oral contraceptives, ethinylestradiol and levonorgestrel. ${ }^{[9]}$ Furthermore, progesterone concentrations were not affected. ${ }^{[9]}$

Other drug-drug interaction studies have shown that lacosamide had no effect on the pharmacokinetics of digoxin, and that there was no clinically relevant interaction between lacosamide and metformin or omeprazole. ${ }^{[9]}$

\section{Efficacy and safety}

\section{Efficacy with concomitant AEDs}

Lacosamide appears to be mechanistically distinct from other AEDs, including traditional sodium channel blocking AEDs such as OXC, LTG, CBZ and PHT. The precise mechanism by which lacosamide exerts its anti-epileptic effects in humans remains to be fully elucidated.

In pooled clinical trials lacosamide showed additional efficacy regardless of the specific concomitant AEDs administered. Most patients in this pooled, secondary analysis had been treated with multiple lifetime AEDs, had a long history of epilepsy, and were utilizing $\geq 2$ concomitant AEDs prior to baseline. Number of subjects on monotherapy was too low 
to allow a meaningful comparison of individual combinations. This analysis suggests that LCM can offer additional efficacy, regardless of existing concomitant AED use. ${ }^{[15]}$

\section{Side effects}

Serious adverse events were not seen in clinical trials for epilepsy after 6 years of testing. Non-serious adverse events are seen mainly during titration. Side effects include ataxia, dizziness, nystagmus and nausea. These side effects are all dose related. There were not idiosynchratic side effects so far.

\section{Formulations, dosage schedule-ease of use}

PB, VPA, PHT/fosphenytoin, LEV and LCM have IV formulations. So far no other new AEDs have IV formulations or are planning to have them. LEV and LTG are available in extended release oral preparations in USA. Since oral tablet and the IV forms are bioequivalent, the ability to switch between each other without changing the dose, provides convenience to the physicians and the patients.

\section{Phase II/III clınıcal trials}

To further evaluate the role of specific AED combinations in clinical outcome, data obtained from 3 clinical trials were combined and analyzed. Post hoc exploratory analyses were performed on the lacosamide pooled Phase II/III trial data (SP667, SP754, SP755) which include only patients who were taking at least 1 traditional sodium channel blocking AED (oxcarbazepine, carbamazepine, lamotrigine or phenytoin ) as part of their concomitant treatment regimen.

\section{Patient eligibility}

Patients with uncontrolled partial-onset seizures with or without secondary generalization for $\geq 2$ years despite prior therapy with $\geq 2$ AEDs, with or without additional vagus nerve stimulation (VNS), aged between 16-70 years, with an average of at least 4 partial-onset seizures per 28 days; seizure-free period $\leq 21$ days in the 8 weeks prior to baseline and during the 8-week baseline phase, being treated with 1-3 concomitant AEDs (1-2 in SP667) were included in these studies.

\section{Study designs}

The primary evaluation of lacosamide for adjunctive therapy in adults with partial-onset seizures is based on 3 similarly designed phase II/III pivotal clinical trials: Study 1 (Phase II, $\mathrm{n}=418$, conducted in the US and Europe), Study 2
(Phase III, $\mathrm{n}=485$, conducted in Europe and Australia), and Study 3 (Phase III, $n=405$, conducted in the US). The 3 trials were similar in design; all were multi-central, randomized, double-blind, placebo-controlled trials to assess the efficacy and safety of LCM as adjunctive therapy in adult subjects with partial-onset seizures. ${ }^{[16,17,18,19]}$

All 3 trials were powered to be adequate and well-controlled studies to evaluate the efficacy and safety of the oral formulations of lacosamide 200,400 , or $600 \mathrm{mg} /$ day vs. placebo in patients with refractory partial-onset seizures taking 1 to 3 AEDs, with or without VNS.

Each of these trials used a fixed-dose, forced-titration design and included a Baseline Phase of 8 weeks to evaluate the baseline seizure frequency. Other phases of these open label studies included a Titration Phase (4- or 6-weeks), a Maintenance Phase (12-week), and a Taper or Transition Phase (2- to 3-weeks). ${ }^{[16,17,18,19]}$

After randomization, the patients began double-blind treatment as follows: a 4- (Study 2) or 6-weeks (Studies 1 and 3) forced titration up to the respective randomized dose of LCM $(200,400$, or $600 \mathrm{mg} /$ day) or placebo (a 1-step, back-titration of LCM $100 \mathrm{mg} /$ day or placebo was allowed in the case of intolerable adverse events at the end of the Titration Phase); a 12-weeks Maintenance Phase on the achieved randomized (or back-titrated) dose; and either a 2-weeks Transition Phase or a 2- (Study 2) or 3-weeks (Studies 1 and 3) Taper Phase. The 2-weeks Transition Phase that brought patients to a dose of LCM $200 \mathrm{mg} /$ day was required for patients who completed the Maintenance Phase and who chose to enroll in an open-label extension trial of LCM. The 2-to 3-weeks Taper Phase (during which dosing was reduced by weekly increments of $200 \mathrm{mg} /$ day) was required for patients who chose not to enroll in the open-label extension trial of LCM or who did not complete the Titration or Maintenance Phases.

A Baseline seizure frequency of $\geq 4$ partial-onset seizures per 28 days on average was deemed sufficiently high to detect both decreases and increases in seizure frequency. An 8-weeks Baseline Phase was considered necessary to adequately assess Baseline seizure frequency due to spontaneous fluctuations of seizure frequency in this subject population. Furthermore, the duration of the Maintenance Phase (12 weeks) was chosen due to regulatory guidance (European Medicines Agency [EMEA]) that suggests a 12- 
week Maintenance Phase to have an adequate duration to evaluate efficacy.

Two primary variables were defined in each of these trials. For the US FDA, the primary variable was the change in partial seizure frequency per 28 days from Baseline to the Maintenance Phase. For the EMEA, the primary variable was the proportion of responders, or patients experiencing $a \geq 50 \%$ reduction in partial seizure frequency from Baseline to the Maintenance Phase. ${ }^{[16,17,18,19]}$

\section{Analysis populations for post-hoc analyses}

The safety set for the pooled data and the subset of patients taking at least one concomitant traditional sodium channel blocking AED included patients who took at least 1 dose of trial medication.

The efficacy set for the pooled data and also the subset of patients taking at least one concomitant traditional sodium channel blocking AED included patients who took at least 1 dose of trial medication and had at least 1 post-baseline efficacy assessment in the Maintenance Phase. Patients who dropped-out during titration are therefore not included as part of the efficacy assessment. By excluding dropouts during Titration, Intention To Treat (ITT) Maintenance analysis better reflects dosing as intended by the protocol while still using an ITT approach for subjects assessed during the Maintenance Phase.

\section{Results}

Demographics: ITT population consisted of 1294 patients with a mean age of 38.6 years. Approximately half of the patients (51.1\%) were females. Most of the patients (91.7\%) were Caucasians and the mean BMI for the ITT population was $26.8 \mathrm{~kg} / \mathrm{m} 2$. Average time since diagnosis was 23.7 years. Almost half of the patients (45.2\%) tried 7 or more AEDs during their lives, and distribution of 1,2 , and 3 concomitant AED usage was $15.5 \%, 62: 4 \%$ and $22.0 \%$, respectively.

The majority (82\%) of the patients in the lacosamide clinical trials were taking at least one traditional sodium channel blocking AED and demographics for this sub-group is similar to the overall pooled patient population. Most patients (78-79\%) had received 4 or more lifetime AEDs, with $45-46 \%$ reporting at least 7 lifetime AEDs. Most patients were using at least 2 AEDs concomitantly, with $22 \%-25 \%$ using 3 AEDs +/- concomitant VNS.
Efficacy (50\% Responder Rates): In patients taking traditional sodium channel blocking AEDs, lacosamide 400 and $600 \mathrm{mg}$ (unapproved dose) showed a significantly greater proportion of $50 \%$ responders compared to placebo.

In both the pooled Phase II/III population and in those treated with traditional sodium channel blocking AEDs, 50\% responder rates were significantly higher in the lacosamide 400 and $600 \mathrm{mg} /$ day dose groups compared to placebo.

While no specific comparisons were done, the $50 \%$ responder rates appeared approximately similar in both groups at approved doses.

Safety: For the group of patients taking at least 1 traditional sodium channel blocking AED, the same treatment emergent adverse events (TEAEs) as in the total Phase II/III population occurred at an incidence of at least $5 \%$ and greater than placebo. There were no additional TEAEs for the sodium channel group that met this criterion. The overall pattern and dose relationship of common AEs was similar in both groups.

The incidence of TEAEs leading to discontinuation in $\geq 1 \%$ of patients randomized to lacosamide in the pooled Phase II/III population and incidence of discontinuation due to those same TEAEs in patients treated with traditional sodium channel blocking AEDs were examined. One additional TEAE (tremor, $1.0 \%$ ) led to discontinuation in $\geq 1 \%$ of patients treated with traditional sodium channel blocking AEDs that did not occur at a rate of $\geq 1 \%$ in the pooled Phase II/III population. Dizziness was the most common TEAE leading to discontinuation in both groups, and was the only TEAE leading to discontinuation in $\geq 5 \%$ of patients. The total percentage of subjects discontinuing for these TEAEs was similar in both groups.

\section{Conclusion}

LCM has a novel mode of action however the precise mechanism by which LCM exerts its anti-epileptic effects in humans remains to be fully elucidated. Adjunctive LCM therapy (400 mg and $600 \mathrm{mg}$ ) demonstrated significant efficacy in patients treated with traditional sodium channel blocking AEDs. Results are consistent with previous data analyses in which efficacy with LCM were demonstrated regardless of concomitant AED treatment regimen. The type and dose relationship of TEAEs appeared to be similar to the overall 
patient pool and LCM is considered to be well tolerated at all dose levels. With its IV formulation LCM will expand the treatment options offered to physicians and patients, providing further convenience with the ability to switch between oral and IV formulations.

\section{References}

1. Online: World Health Organization (WHO). Available at: http:// www.who.int/mediacentre/factsheets/fs999/en/ (Date of access:17 November 2014)

2. Hauser WA, Annegers JF, Kurland LT. Incidence of epilepsy and unprovoked seizures in Rochester, Minnesota: 1935-1984. Epilepsia 1993;34(3):453-68. CrossRef

3. Hauser A. Incidence and Prevalence in Epilpesy: A comprehensive textbook. Philadelphia, PA: Lippincot Raven; 1998. p. 47-57.

4. Online: Epilepsy Foundation. Available at: http://www.epilepsy.com/learn/epilepsy-statistics (Date of access:17 November 2014)

5. de Bittencourt PR, Adamolekum B, Bharucha N, Carpio A, Cossío OH, Danesi MA, et al. Epilepsy in the tropics: I. Epidemiology, socioeconomic risk factors, and etiology. Epilepsia 1996;37(11):1121-7. CrossRef

6. Velioglu SK, Bakirdemir M, Can G, Topbas M. Prevalence of epilepsy in northeast Turkey. Epileptic Disord 2010;12(1):22-37.

7. Calişir N, Bora I, Irgil E, Boz M. Prevalence of epilepsy in Bursa city center, an urban area of Turkey. Epilepsia 2006;47(10):1691-9.

8. French JA, Kanner AM, Bautista J, Abou-Khalil B, Browne T, Harden $\mathrm{CL}$, et al. Efficacy and tolerability of the new antiepileptic drugs II: treatment of refractory epilepsy: report of the Therapeutics and Technology Assessment Subcommittee and Quality Standards Subcommittee of the American Academy of Neurology and the American Epilepsy Society. Neurology 2004;62(8):1261-73. CrossRef

9. VIMPAT $^{\circledR}$ (lacosamide). Summary of Product Characteristics. UCB, 25 October 2010.
10. Beydoun A, D'Souza J, Hebert D, Doty P. Lacosamide: pharmacology, mechanisms of action and pooled efficacy and safety data in partial-onset seizures. Expert Rev Neurother 2009;9(1):33-42. CrossRef

11. Errington AC, Stöhr T, Heers C, Lees G. The investigational anticonvulsant lacosamide selectively enhances slow inactivation of voltage-gated sodium channels. Mol Pharmacol 2008;73(1):157-69. CrossRef

12. Niespodziany I, Leclère $N$, Vandenplas $C$, et al. Comparative study of lacosamide with classic sodium channel blocking antiepileptic drugs on sodium current slow inactivation. Poster presented at the 9th European Congress on Epileptology, Rhodes 2010.

13. Jatuzis D, Biton V, Ben-Menachem E, et al; and the SP667 Study Group. Evaluation of the effect of oral lacosamide on adjunctive concomitant antiepileptic drug plasma concentrations in subjects with partial seizures. Poster presented at the 10th Congress of the European Federation of Neurological Societies, Glasgow 2006.

14. UCB Pharma SA. Data on file.

15. Rosenfeld W, Rudd D, Hebert D, et al. Lacosamide efficacy is independent of concomitant AED treatment. Poster presented at: 62nd Annual American Epilepsy Society Meeting; December 5-9, 2008; Seattle, WA.

16. Ben-Menachem E, Biton V, Jatuzis D, Abou-Khalil B, Doty $P$, Rudd GD. Efficacy and safety of oral lacosamide as adjunctive therapy in adults with partial-onset seizures. Epilepsia 2007;48(7):1308-17. CrossRef

17. Halász $P$, Kälviäinen $R$, Mazurkiewicz-Beldzińska $M$, Rosenow $F$, Doty $\mathrm{P}$, Hebert $\mathrm{D}$, et al. Adjunctive lacosamide for partial-onset seizures: Efficacy and safety results from a randomized controlled trial. Epilepsia 2009;50(3):443-53. CrossRef

18. Chung S, Sperling MR, Biton V, Krauss G, Hebert D, Rudd GD, et al. Lacosamide as adjunctive therapy for partial-onset seizures: a randomized controlled trial. Epilepsia 2010;51(6):958-67. CrossRef

19. Data on File; UCB, Inc. 